\title{
Acid-induced esophageal shortening in humans: A cause of hiatus hernia?
}

\author{
Donal P Dunne MD, William G Paterson MD
}

\begin{abstract}
DP Dunne, WG Paterson. Acid-induced esophageal shortening in humans: A cause of hiatus hernia? Can J Gastroenterol 2000;14(10):847-850.
\end{abstract}

BACKGROUND: Hiatus hernia and gastroesophageal reflux disease commonly coexist, and there is pathophysiological evidence that the presence of a hiatus hernia contributes to abnormal acid reflux. However, the cause of hiatus hernia remains unclear. In an animal model, it has been shown that acute acid injury to the esophagus results in esophageal shortening, raising the possibility that reflux esophagitis per se can contribute to the formation of hiatus hernia by inducing esophageal shortening.

AIM: To determine whether luminal acid produces esophageal shortening in humans.

METHODS: Twelve volunteers were each studied on two occasions, one week apart, in a double-blind, crossover trial. The location of the lower esophageal sphincter (LES), as well as the LES resting pressure and axial length were determined at baseline and then again after $20 \mathrm{~min}$ of either acid or saline perfusion.

RESULTS: Acid perfusion did not induce significant changes in resting LES pressure but resulted in proximal migration of the LES (ie, esophageal shortening) by an average of $0.5 \mathrm{~cm}$, with the largest proximal migration being $1.8 \mathrm{~cm}$. In contrast, saline perfusion resulted in slight distal migration of the LES (ie, esophageal lengthening).

CONCLUSIONS: Intraluminal acid perfusion causes longitudinal axis shortening of the esophagus and suggests that gastroesophageal acid reflux may contribute to the cause of hiatus hernia.

Key Words: Acid perfusion; Esophagitis; Lower esophageal sphincter; Manometry

\section{Raccourcissement de l'œsophage induit par l'acide chez l'être humain : Cause de l'hernie hiatale?}

HISTORIQUE : L'hernie hiatale et le reflux gastro-œsophagien s'observent souvent concomitamment et selon des preuves pathophysiologiques, la présence de l'hernie hiatale contribue au reflux acide anormal. Par contre, l'étiologie de l'hernie hiatale reste imprécise. Dans un modèle animal, on a démontré que une atteinte aiguë causée par l'acide au niveau de l'œsophage entraîne un raccourcissement de l'œsophage, suggérant la possibilité qu'une l'œsophagite de reflux en soi contribue à la formation de l'hernie hiatale en induisant un raccourcissement de l'œsophage.

BUT : Déterminer si la présence d'acide dans la lumière produit un raccourcissement de l'œsophage chez l'être humain.

MÉTHODE : Douze volontaires ont été examinés à une semaine d'intervalle à l'aide d'un protocole à double insu avec permutation des groupes. La localisation du sphincter œsophagien inférieur (SOI) et la mesure de sa pression au repos et de sa longueur axiale ont été déterminées au départ, puis à nouveau après 20 minutes d'une perfusion de solution acide ou saline.

RÉSULTATS : La perfusion acide n'a pas provoqué de changement significatif des pressions du SOI au repos, mais a occasionné une migration proximale du SOI (c.-à-d. raccourcissement œsophagien) en moyenne de $0,5 \mathrm{~cm}$, les portions de migration proximale les plus importantes étant de $1,8 \mathrm{~cm}$. En revanche, la perfusion saline a entraîné une migration distale légère du SOI (c.-à-d. allongement de l'œsophage).

CONCLUSION : La perfusion intra-luminale d'acide provoque un raccourcissement de l'axe longitudinal de l'œsophage et suggère que le reflux d'acide gastro-œsophagien puisse contribuer à l'hernie hiatale.
$\mathrm{I}^{\mathrm{n}}$ $\mathrm{n}$ the past decade, there has been renewed interest in the role of hiatus hernia in the pathogenesis of gastroesophageal reflux disease (GERD). Hiatus hernia and GERD commonly coexist $(1,2)$, and the hernia sac can act as an acid reservoir that allows ready access of acidic juice into the esophagus whenever the lower esophageal sphincter (LES) relaxes, thus contributing to prolonged esophageal acid exposure $(3,4)$. The crural fibres of the diaphragm are also thought to provide an external bolster to the LES, thereby contributing to the antireflux barrier $(5,6)$. While there is 


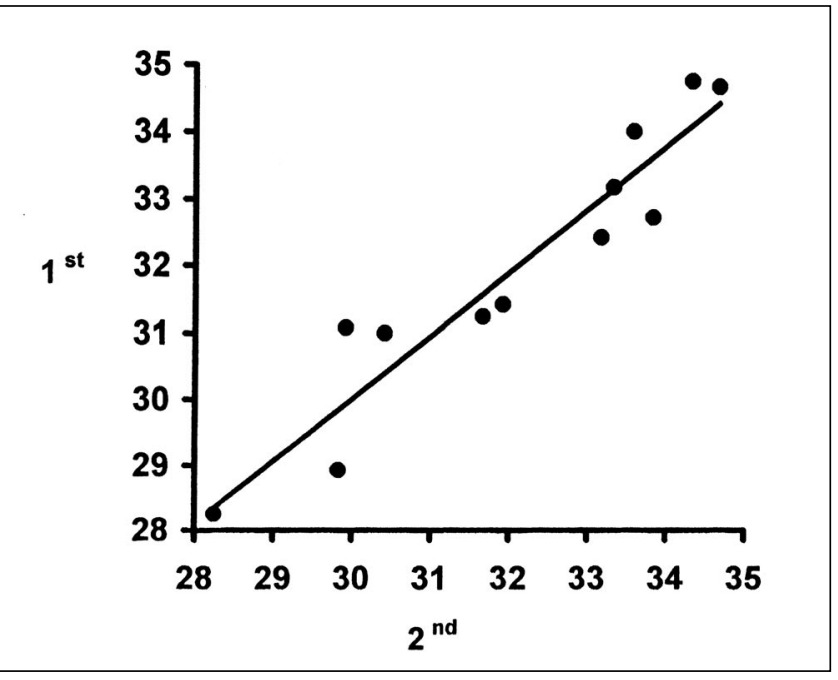

Figure 1) Linear regression analysis demonstrating the reproducibility of the lower esophageal sphincter manometric mapping technique in determining the proximal margin of lower esophageal sphincter relative to nares in centimetres. Baseline (ie, before perfusion) measurements were compared between the first and second studies, conducted seven days apart. $(r=0.95 ; P<0.0001)$

good evidence that a hiatus hernia contributes to the pathogenesis of GERD, little is known about how the hernia actually forms. The traditional explanation is that laxity of the ligamentous structures around the hiatus occurs, which allows the stomach to migrate upwards into the chest, particularly in the setting of increased abdominal pressure caused, for instance, by obesity (7). This hypothesis is not supported by experimental evidence. Furthermore, it does not explain the fundamental prerequisite for the development of hiatus hernia - esophageal shortening. Recent studies have demonstrated, in an animal model, that acute intraluminal acid perfusion induces esophageal shortening (8) that can be prevented by pretreatment with a mast cell stabilizer (9). This suggests that acid injury to the esophageal mucosa causes release of mast cell mediators, which in turn cause longitudinal muscle contraction and esophageal shortening. If this also occurs in humans, it would provide a mechanism whereby hiatus hernia could develop and enlarge in the setting of ongoing gastroesophageal reflux. The objective of the present study, therefore, was to determine whether acid-induced esophageal shortening also occurs in humans.

\section{SUBJECTS AND METHODS}

The study was approved by the Queen's University Human Ethics Review Board, and all participants gave informed, written consent. Twelve healthy volunteers (seven females; age range 23 to 65 years), free of all esophageal symptoms, were each studied on two occasions, one week apart, in a randomized, double-blind crossover trial. Subjects were randomly allocated to receive intraluminal perfusion of $0.1 \mathrm{~N}$ hydrochloric acid or normal saline on day 1 , and then received the alternate infusion on day 8 . Subjects were studied at the same time each day (early afternoon) and had fasted for at least $4 \mathrm{~h}$ before the study. Intraluminal manometry was performed using a custom-made perfused catheter system (Mui Scientific, Canada) with six radially oriented pressure ports located $0.5 \mathrm{~cm}$ apart at the distal end and another perfusion port located $10 \mathrm{~cm}$ proximally. The catheter was passed transnasally such that all distal ports were initially located in the stomach, and then a slow station pullthrough of the LES was performed in $0.5 \mathrm{~cm}$ increments, so that all six distal leads were used to map out the LES. Line markings on the catheter at $0.5 \mathrm{~cm}$ intervals facilitated the station pullthrough. After withdrawing the catheter each $0.5 \mathrm{~cm}$ increment, the technician annotated catheter position on the computer tracing and held that position for at least $20 \mathrm{~s}$. Thus, each data point for a subject comprised a mean of six observations. The catheter was then positioned so that the distal pressure ports straddled the LES. The proximal port, located approximately $10 \mathrm{~cm}$ above the LES, was then used to perfuse the esophagus with either $0.1 \mathrm{~N}$ hydrochloric acid or normal saline at a rate of $5 \mathrm{~mL} / \mathrm{min}$ for $20 \mathrm{~min}$. The catheter was then advanced so that all distal ports were once again located in the stomach, and the slow station pullthrough was repeated. The subject was not aware which infusate was being used. Recordings were made and analyzed using the PC Polygraf HR data acquisition system and Polygram Upper GI edition version 6.4 software, respectively (Synectics Medical, Sweden). Tracings were coded, stored on disk and subsequently analyzed by a blinded observer. The following three variables were measured.

- Resting LES pressure, which was taken as the end expiratory pressure at the highest pressure point in the LES where the baseline was stable. Regions of postrelaxation contraction were excluded.

- LES location relative to external nares (a measure of esophageal length), which was assessed by determining the point at which the LES was entered and exited during the slow station pullthrough. The gastric side of the LES was taken as the first point where a sustained elevation of baseline over gastric pressure was seen. The proximal margin of the LES was defined as the point where respiratory reversal had occurred and esophageal body pressures were recorded.

- The axial length of the LES, which was defined as the distance in centimeters from the distal to the proximal margin of the LES.

Data are expressed in terms of the change from baseline (ie, before and after infusion of either saline or acid), and statistical comparisons were made between the saline perfusion and acid perfusion days with the Mann-Whitney test. Linear regression analysis was used to determine the reproducibility of the pullthrough techniques in establishing the proximal margin of the LES. $\mathrm{P}<0.05$ was considered significant. Data are expressed as mean \pm SEM.

\section{RESULTS}

Reproducibility of manometric localization of LES: To determine the reproducibility of the LES mapping technique in establishing LES location relative to the nares (and hence 


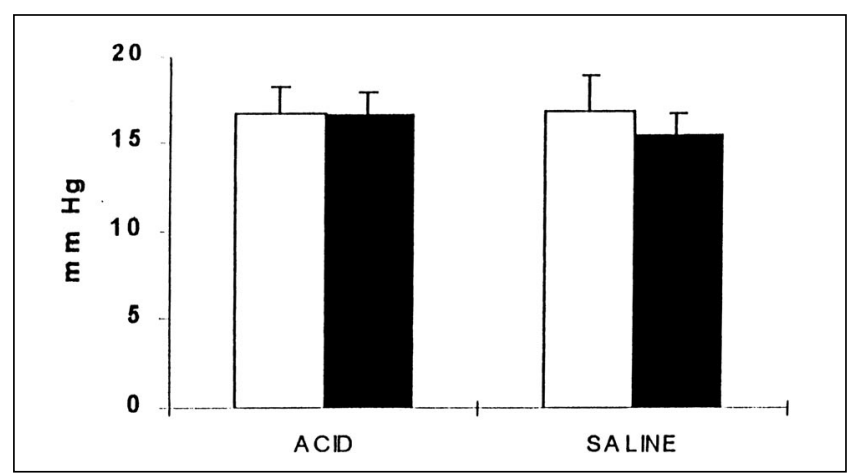

Figure 2) Effect of esophageal acid or saline perfusion on resting lower esophageal sphincter pressure. There was no significant change in resting lower esophageal sphincter pressure between baseline (open bars) and after perfusion (black bars) for either saline or acid perfusion

esophageal length), the baseline pullthroughs performed on the two study days were compared. There was a highly significant correlation between the manometrically defined proximal margin of the LES in the same individual studied one week apart $(\mathrm{r}=0.95 ; \mathrm{P}<0.0001)$ (Figure 1$)$.

Effect of acid perfusion on resting LES pressure: Resting LES pressures remained stable before and after esophageal perfusion (Figure 2). There was no difference in resting LES pressure between the acid perfusion and saline perfusion days. Effect of acid perfusion on LES location and LES axial length: Figure 3 shows the variable of primary interest - the change in LES position as a measure of esophageal length. With saline perfusion, the LES migrated slightly distally, indicating esophageal lengthening. Acid perfusion resulted in a significant $(\mathrm{P}=0.016)$ proximal migration of the LES that averaged $0.5 \pm 0.2 \mathrm{~cm}$, with a shortening of $1.8 \mathrm{~cm}$ occurring in one subject.

The axial length of the LES itself also appeared to decrease in the acid-perfused group compared with the salineperfused group (Figure 4), although this difference was not statistically significant $(\mathrm{P}=0.16)$.

\section{DISCUSSION}

These studies confirm that, in humans, intraluminal acid exposure of a duration similar to that which can occur in GERD (10), results in significant esophageal shortening, as measured by proximal migration of the LES. This result is similar to that seen in the opossum model $(8,9)$ and raises the intriguing possibility that reflux esophagitis might contribute to the formation of a hiatus hernia.

A large, fixed hiatus hernia can make reflux worse by providing an acid reservoir with ready access to the LES $(3,4)$. Also, if normally located, the crural fibres of the diaphragm may buttress the region of the LES, thereby contributing to the gastroesophageal pressure barrier $(5,6)$. However, children with abnormal reflux usually do not have a hiatus hernia unless severe esophagitis is present (11). It is, therefore, conceivable that abnormal reflux, primarily triggered by pathological transient LES relaxations (12), may result in longitudinal axis shortening of the esophagus, which, in

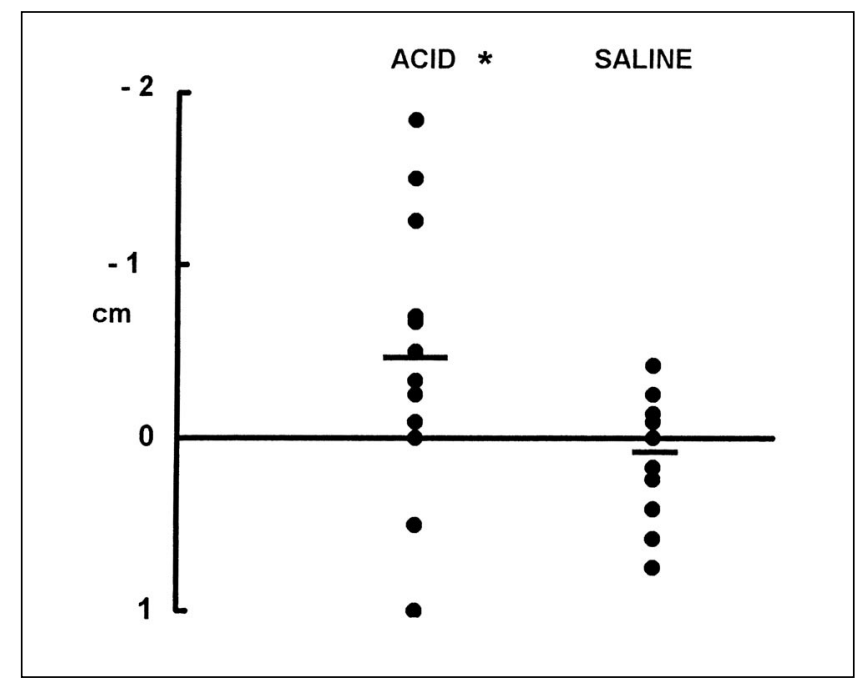

Figure 3) Effect of esophageal acid or saline perfusion on esophageal length. The data are presented as the change in esophageal length relative to baseline (ie, before perfusion). Each data point represents one subject, and the horizontal lines represent the means for the 12 subjects. Saline perfusion resulted in an average net lengthening of the esophagus (ie, distal migration of lower esophageal sphincter), whereas acid perfusion resulted in significant esophageal shortening (ie, proximal migration of lower esophageal sphincter). The data are more tightly clustered on the saline perfusion day, whereas there was more interindividual variability after acid perfusion. Shortening of $0.5 \mathrm{~cm}$ did not occur with saline perfusion, whereas half of the subjects had $0.5 \mathrm{~cm}$ shortening with acid perfusion. $* P=0.016$ compared with saline perfusion

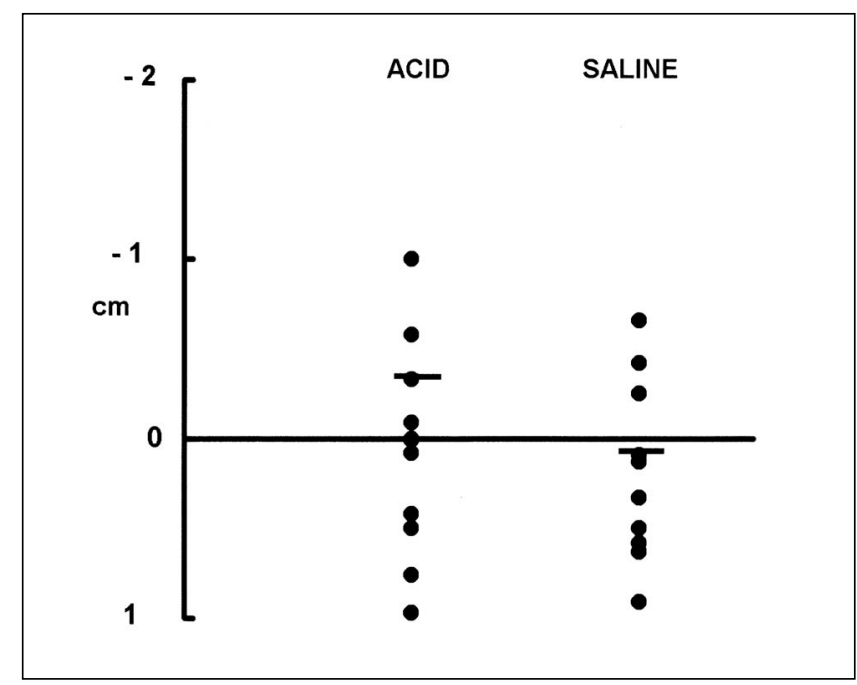

Figure 4) Effect of acid or saline perfusion on axial length of the lower esophageal sphincter (LES). The data are presented as the change in axial length relative to baseline (ie, before perfusion). Each data point represents one subject, and the horizontal lines represent the means for the 12 subjects. The axial lower esophageal sphincter length appears to shorten after acid perfusion, but this difference was not statistically significant $(P=0.16)$

turn, may contribute to the formation of a hiatus hernia. Once formed, a vicious cycle may be established, whereby the hernia exacerbates reflux, which in turn induces more esophageal shortening and the production of a larger hernia. 
The mechanism for this acid-induced esophageal shortening is unclear. In the opossum model, acute intraluminal acid perfusion causes esophageal shortening that appears to be caused by sustained contraction of the longitudinally oriented esophageal musculature. This is not affected by anticholinergic agents or bilateral cervical vagotomy (8). However, pretreatment of the animals with mast cell stabilizers can completely prevent the shortening (9). Luminal acid perfusion of short duration has been shown to result in mast cell degranulation in the opossum esophagus (13), and the histamine released from the mast cells mediates the augmentation of esophageal blood flow triggered by the luminal acid (14). Furthermore, the lamina propria of the human esophagus contains a large number of mast cells, similar to the number seen in the opossum model $(15,16)$.

Although the degree of esophageal shortening induced in our experiments was relatively small $(0.5 \mathrm{~cm}$ on average), there were three subjects in whom the shortening was more than $1.0 \mathrm{~cm}$. Furthermore, with acid perfusion, one-half of the subjects had $0.5 \mathrm{~cm}$ or greater shortening recorded, whereas shortening of this magnitude was never recorded after saline perfusion. It is unclear why significant acidinduced shortening was confined to a subset of individuals studied. When subjects with significant acid-induced shortening were compared with those in whom acid did not induce significant shortening, no significant difference in resting LES pressure or length was revealed. This degree of shortening occurred after only a single, $20 \mathrm{~min}$ acid exposure and may have been considerably greater with repeated acid exposures. Shirazi et al (17) induced severe esophagitis in opossums by performing prolonged $(4 \mathrm{~h})$ acid perfusion and then studied the motility of the esophagus $72 \mathrm{~h}$ later. In this study, the esophagus was shortened by up to $2 \mathrm{~cm}$. Prelimi-

\section{REFERENCES}

1. Sontag SJ, Schnell TG, Miller TQ, et al. The importance of hiatal hernia in reflux esophagitis compared with lower esophageal sphincter pressure or smoking. J Clin Gastroenterol 1991;13:628-43.

2. Peterson H, Johannessen T, Sandvik AK, et al. Relationship between endoscopic hiatus hernia and gastroesophageal reflux symptoms. Scand J Gastroenterol 1991;26:921-6.

3. Mittal RK, Lange RC, McCallum RW. Identification and mechanism of delayed esophageal acid clearance in subjects with hiatus hernia. Gastroenterology 1987;92:130-5.

4. Sloan S, Kahrilas PJ. Impairment of esophageal emptying with hiatal hernia. Gastroenterology 1991;100:596-605.

5. Boyle JT, Altschuler SM, Nixon TE, Tuchman DN, Pack AI, Cohen $\mathrm{S}$. The role of the diaphragm in the genesis of lower esophageal sphincter pressure in the cat. Gastroenterology 1985;88:723-30.

6. Mittal RD, Rochester DF, McCallum RW. Effect of the diaphragmatic contraction on lower esophageal sphincter pressure in man. Gut 1987;28:1564-8.

7. Kerr RM. Hiatal hernia and mucosal prolapse. In: Castell DO, ed. The Esophagus. Boston: Little, Brown and Co, 1992:759-80.

8. Paterson WG, Kolyn DM. Esophageal shortening induced by short-term intraluminal acid perfusion in opossum: A cause for hiatus hernia? Gastroenterology 1994;107:1736-40.

9. Paterson WG. Role of mast cell-derived mediators in acid-induced shortening of the esophagus. Am J Physiol 1998;274:G385-8.

10. Demeester TR, Johnson LF, Joseph GJ, Toscano MS, Hall AW, Skinner DB. Patterns of gastroesophageal reflux in health and disease. Ann Surg 1976;184:459-69. nary studies (18) have been conducted in which the opossum esophagus was perfused with acid for $45 \mathrm{~min}$ on three successive days. Measurements on the fourth day showed a persisting shortening of approximately $1.5 \mathrm{~cm}$.

The validity of our results depends on the reliability of using changes in manometric location of the LES to assess changes in esophageal length. Manometric mapping of the LES has been used by others in comparing differences in LES length between control subjects and patients with hiatus hernia (19), and in the present study, we demonstrated a high degree of reproducibility when these measurements were performed one week apart. Furthermore, all our tracings were coded and analyzed by a blinded observer. Thus, it is highly unlikely that the proximal LES migration recorded after acid perfusion, but not after saline perfusion, was a chance event. Such a proximal migration could not be explained by anything other than esophageal shortening, unless it had been accompanied by an increase in the axial length of the gastroesophageal high pressure zone. In the present study, however, LES axial length decreased after acid perfusion.

Clearly, our observations with short duration acid perfusion in healthy volunteers do not prove that reflux esophagitis contributes to hiatus hernia. However, this is the first human experimental study directed at the cause of hiatus hernia, and when taken in combination with the animal data, should make us revisit our thinking on the pathophysiological relationship between hiatus hernia and GERD.

ACKNOWLEDGEMENTS: This study was supported by the Medical Research Council of Canada, grant \#MT 9978.

11. Shepherd RW, Wren J, Evans S, Lander M, Ong TH. Gastroesophageal reflux in children. Clinical profile, course and outcome with active therapy in 126 cases. Clin Pediatr 1987;26:55-60.

12. Dodds WJ, Dent J, Hogan WJ, et al. Mechanisms of gastroesophageal reflux in patients with reflux esophagitis. N Engl J Med 1982;307:1547-52.

13. Barclay RL, Dinda PK, Morris GP, Paterson WG. Morphological evidence of mast cell degranulation in an animal model of acid-induced esophageal mucosal injury. Dig Dis Sci 1995;269:G219-24.

14. Feldman MJ, Morris GP, Dinda PK, Paterson WG. Mast cells mediate acid-induced augmentation of opossum esophageal blood flow through a histamine- and nitric oxide-dependent mechanism. Gastroenterology 1996;110:121-8.

15. Ying LTJ, Hurlbut DJ, Paterson WG. Human mucosal mast cell number and relationship to vasculature in acid-induced inflammatory conditions of the esophagus. Can J Gastroenterol 1996;10(Suppl A):51A. (Abst)

16. Marinell F, Odze R, Furuta GT, Spechler S, Wershil BK. Mast cell numbers in the esophagus are increased in association with specialized intestinal metaplasia. Gastroenterology 1995;108:A159. (Abst)

17. Shirazi S, Schulze-Delrieu K, Custer-Hagen T, Brown CK, Ren J. Motility changes in opossum esophagus from experimental esophagitis. Dig Dis Sci 1989;34:1668-76.

18. White RJ, Morris GP, Miller DV, Paterson WG. Esophageal shortening in opossum: the earliest motor disorder in acid-induced esophagitis? Gastroenterology 1999;116:A353. (Abst)

19. Kahrilas PJ, Wu S, Lin S, Pouderoux P. Attenuation of esophageal shortening during peristalsis with hiatus hernia. Gastroenterology 1995;109:1818-25. 


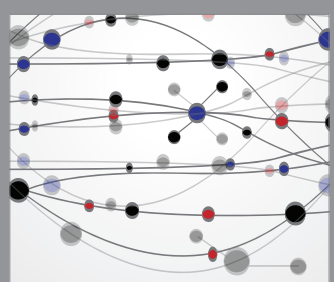

The Scientific World Journal
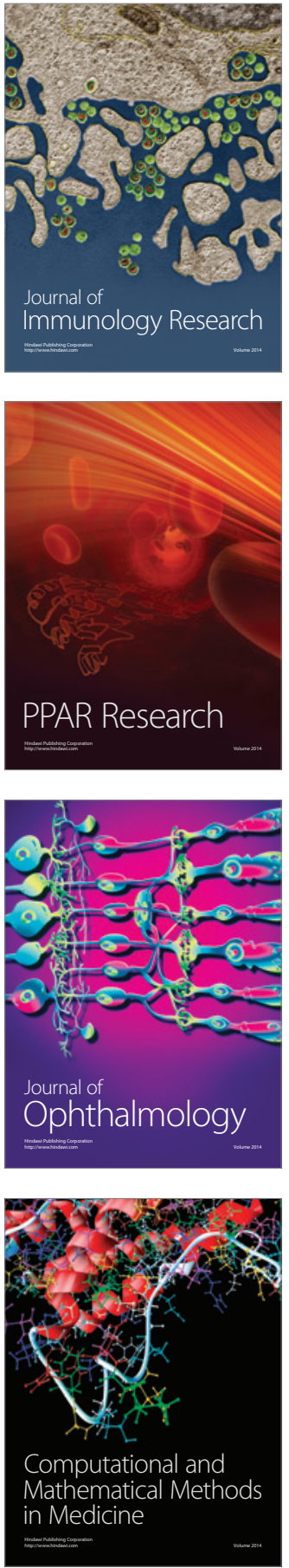

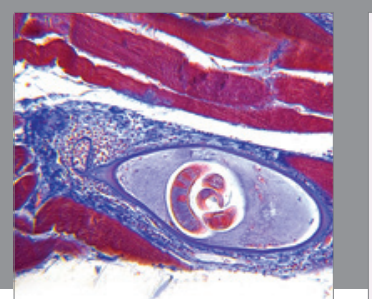

Gastroenterology Research and Practice

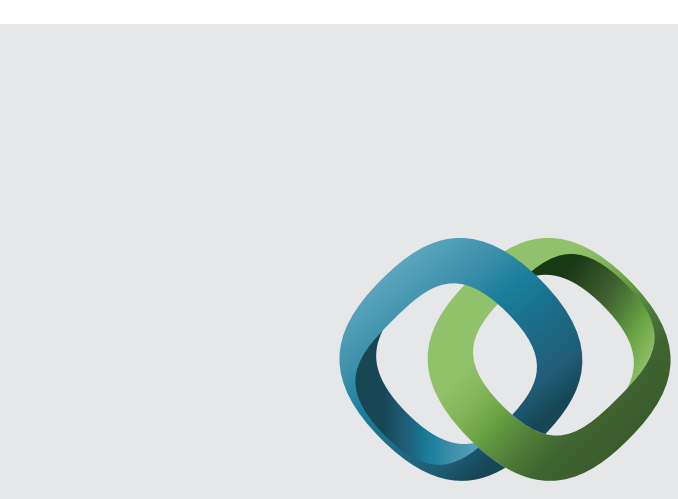

\section{Hindawi}

Submit your manuscripts at

http://www.hindawi.com
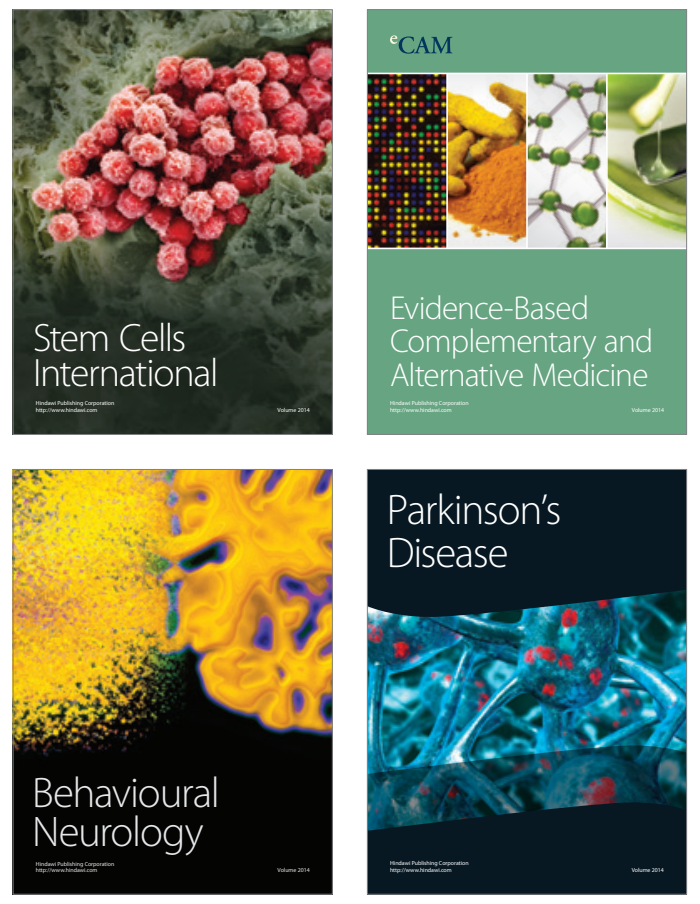
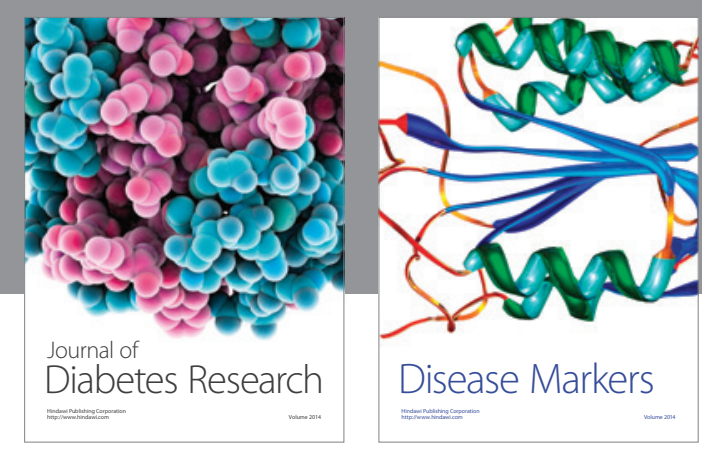

Disease Markers
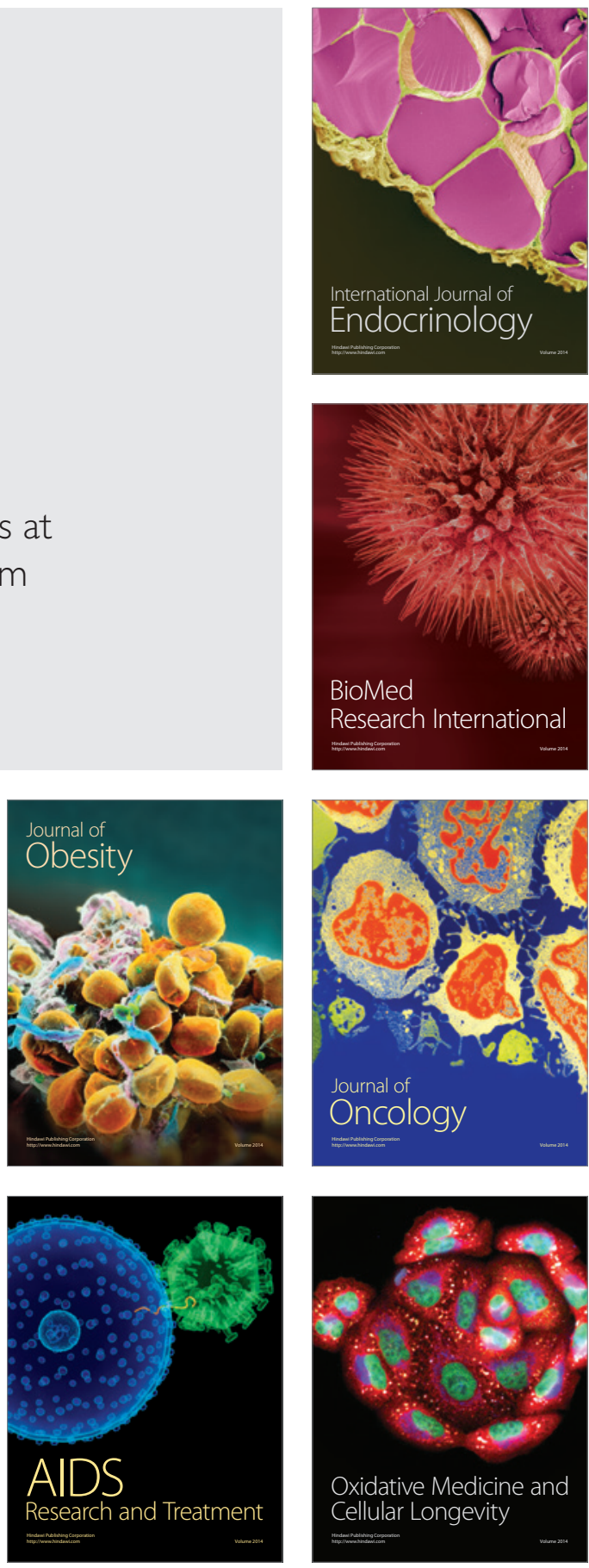